\title{
Virus Infections in Type 1 Diabetes
}

\author{
Ken T. Coppieters, Tobias Boettler, and Matthias von Herrath \\ Center for Type 1 Diabetes Research, La Jolla Institute for Allergy and Immunology, La Jolla, \\ California 92037 \\ Correspondence: matthias@liai.org
}

The precise etiology of type 1 diabetes (T1D) is still unknown, but viruses have long been suggested as a potential environmental trigger for the disease. However, despite decades of research, the body of evidence supporting a relationship between viral infections and initiation or acceleration of islet autoimmunity remains largely circumstantial. The most robust association with viruses and T1D involves enterovirus species, of which some strains have the ability to induce or accelerate disease in animal models. Several hypotheses have been formulated to mechanistically explain how viruses may affect islet autoimmunity and $\beta$-cell decay. The recent observation that certain viral infections, when encountered at the right time and infectious dose, can prevent autoimmune diabetes illustrates that potential relationships may be more complex than previously thought. Here, we provide a concise summary of data obtained in mouse models and humans, and identify future avenues toward a better characterization of the association between viruses and T1D.

\section{WHY AN ENVIRONMENTAL FACTOR FOR T1D?}

\begin{abstract}
lthough there is a well-documented genetic Abasis for T1D, its rising incidence in developed countries has to be attributed to environmental changes (Bodansky et al. 1992; Gillespie et al. 2004). Population genetics simply do not change enough between generations to account for the dramatic surge in T1D prevalence as observed in, for example, Finland (Harjutsalo et al. 2008). Moreover, varying disease penetrance rates and the differing ages of disease onset in monozygotic twins are suggestive of nongenetic variables in T1D pathogenesis (Redondo et al. 2008). It has been postulated that the largest increase in disease frequency is occurring in the
\end{abstract}

most developed countries, following a north to south gradient that is reminiscent of the distribution seen in other autoimmune diseases (Borchers et al. 2010). Indeed, the "hygiene hypothesis" has frequently been referenced in this context to explain high ratios of autoimmune disease by the relative lack of exposure to infectious agents (Bach 2002). This theory, as well as the relationship between hygiene standards and T1D incidence is, however, far from absolute as exemplified by the second-highest worldwide incidence in Sardinia, Italy or the substantially lower incidences found in the countries surrounding Finland, which has the world's highest rate. This article will provide an overview of the data that support the implication of viruses as environmental triggers of islet autoimmunity in T1D.

Editors: Jeffrey A. Bluestone, Mark A. Atkinson, and Peter R. Arvan

Additional Perspectives on Type 1 Diabetes available at www.perspectivesinmedicine.org

Copyright (C) 2012 Cold Spring Harbor Laboratory Press; all rights reserved; doi: 10.1101/cshperspect.a007682

Cite this article as Cold Spring Harb Perspect Med 2012;2:a007732 
K.T. Coppieters et al.

\section{HISTORY OF VIRAL ASSOCIATIONS WITH T1D}

\section{Suspects Released without Charge}

It has long been acknowledged in the medical literature that T1D onset within populations follows a seasonal pattern; a finding which initially led to the formulation of a viral etiology (Adams 1926 ). Ever since, a variety of viruses have come under scrutiny as potential inducers of T1D. In the majority of cases, however, associations are weak, irreproducible, or were in some instances convincingly disproved. Examples of initially promising data include reports on T1D association with cytomegalovirus (CMV) (Pak et al. 1988), parvovirus (Guberski et al. 1991; Kasuga et al. 1996), encephalomyocarditis virus (Craighead and McLane 1968), and retroviruses (Conrad et al. 1997), all of which were challenged or are awaiting scientific replication.

Rotaviruses, responsible for a significant share of childhood gastroenteritis, have also been subjected to investigation for their relationship to T1D. Interest was sparked by the demonstration of sequence analogies between T-cell epitopes within the islet antigens GAD and IA-2 and rotavirus protein, suggesting potential cross-reactivity mechanisms (Honeyman et al. 1998). An association between rotavirus infection and islet autoantibody positivity in at-risk children was reported (Honeyman et al. 2000), but later challenged by studies in the Finnish population (Blomqvist et al. 2002; Makela et al. 2006). Therefore, it can be concluded that the role of rotavirus in the etiology of T1D is unconfirmed.

Congenital rubella infection and subsequent onset of diabetes after birth constitutes an interesting paradigm (Gale 2008). Congenital rubella syndrome encompasses an array of physical and behavioral abnormalities. Of note, diabetes development is associated with the presence of the DR3-DQ2 T1D susceptibility haplotype (Menser et al. 1974). It is thought that the virus causes diabetes by disturbing the normal development of $\beta$-cell mass, rather than inducing islet autoimmunity (Patterson et al. 1981). Since the introduction of an effi- cient vaccine in 1969, the virus has been largely eliminated in developed countries, and thus is not expected to be a factor in the current increase of T1D incidence. Beyond this, the mere notion of whether this form of diabetes has any relationship to T1D also remains in doubt (Gale 2008).

Mumps infection has also been implicated in some instances, including a recent report documenting a case of "fulminant" T1D (Goto et al. 2008). In analogy to rubella, however, efficacious vaccination programs have not been able to curb the rising T1D incidence levels (Honeyman 2005).

\section{Enteroviruses and T1D: A Long History}

The most robustly documented correlation between a virus and T1D has been with enteroviruses, a viral single-stranded RNA (ssRNA) genus belonging to the picornaviruses. A recent meta-analysis by Yeung and coworkers established that there is a clinically significant association between enterovirus infection, detected with molecular methods, and T1D (Yeung et al. 2011). Early reports suggesting a link between coxsackievirus, a member of the enterovirus genus, and T1D showed higher neutralizing antibody titers in serum from recent-onset patients as compared to nondiabetic subjects (Gamble et al. 1969), and were later confirmed using conventional polymerase chain reaction (PCR) testing (Clements et al. 1995). Some studies simultaneously probed for antibodies against other viruses and found that the most significant association was with coxsackievirus (Banatvala et al. 1985).

Cross-sectional studies have focused predominantly on recent-onset individuals with T1D, although enterovirus was also identified as a risk factor in prediabetic children (Sadeharju et al. 2001) and pregnant women (Dahlquist et al. 1995; Hyoty et al. 1995; Elfving et al. 2008). There is still a lack of large prospective studies that establish a clear temporal relation between enterovirus infection and the development of islet autoimmunity. That said, two recent studies offer support for a causative role for enteroviruses in T1D. Studying blood 
samples collected by the Diabetes and Autoimmunity Study in the Young (DAISY) consortium, Stene et al. found that the rate of progression from islet autoimmunity (detection of islet autoantibodies) to T1D was significantly increased following detection of enteroviral RNA in serum (Stene et al. 2010). Oikarinen and colleagues further showed that detection of enterovirus RNA is associated with increased risk for the primary development of islet autoimmunity, with a peak infection frequency during the 6 mo window that precedes the appearance of islet autoantibodies (Oikarinen et al. 2011). In combination, these reports suggest that enteroviruses may be involved in both the initiation of islet autoimmunity as well as progression to overt hyperglycemia and thus, act at multiple stages of disease development.

The timing of enteroviral infection as related to T1D onset is, in a sense, an altogether unresolved issue. Data from the nucleotide oligomerization domain (NOD) mouse seem to favor a scenario in which insulitis serves as a prerequisite for coxsackievirus to be diabetogenic (see next section) (Horwitz et al. 2001; Drescher et al. 2004). Susceptible individuals may thus suffer from subclinical insulitis for years before a viral challenge eventually culminates in hyperglycemia.

The notion that any potential association is not absolute and depends, to a considerable degree, on genetic susceptibility, or perhaps acts in concert with other environmental factors, is supported by several studies noting no such correlation (Fuchtenbusch et al. 2001; Graves et al. 2003). A 1971 study followed the diabetes incidence rate after a well-documented epidemic of coxsackievirus B4 (CVB4) infection in the remote Pribilof Islands (Alaska, USA). Five years later, the incidence of diabetes in the infected versus noninfected persons was found to be unaffected (Dippe et al. 1975). CVB4 isolates do, reportedly, have the intrinsic capacity to infect $\beta$ cells and cause insulitis and diabetes in susceptible mouse strains (Yoon et al. 1978) following their direct isolation from a child after their onset of T1D (Yoon et al. 1979). Despite the virus' perceived islet tropism, host susceptibility or additional environmental factors are thus required for diabetogenicity. That said, some of these facets, including the identification of multiple strains (isolated from human pancreata) having the ability to induce diabetes remain rare in reports, and require more in the way of additional study.

\section{ANIMAL MODELS AND MECHANISMS BY WHICH VIRUSES COULD IMPACT T1D}

\section{Animal Models for Studies of the Role for Viruses in T1D}

Despite their shortcomings, animal models remain indispensable tools to map pathological mechanisms. Although the use of rodents in T1D research is discussed in a distinct article of this collection, we will summarize here which viruses have shown the ability to induce or alter experimental diabetogenic responses in vivo.

\section{Mice}

One of the oldest known and most unequivocal relationships between viral infection and diabetes development was revealed after inoculation of mice with encephalomyocarditis virus (EMC; picornavirus, ssRNA) (Craighead and McLane 1968). Diabetes induction usually occurs 3-4 d after infection and critically depends on the virus variant used (Onodera et al. 1978b), dosing (Baek and Yoon 1991), and the genetic background of the host (Onodera et al. 1978b). The virus induces diabetes after specifically infecting pancreatic $\beta$ cells followed by direct cytolysis (high dose) or the recruitment of macrophages (low dose) (Baek and Yoon 1991; Yoon and Jun 2006). Parallels have been drawn between this model and the acute subform of fulminant diabetes that is found in the Japanese population based on its rapid and aggressive onset, exocrine tissue damage, and lack of autoantibodies (Shimada and Maruyama 2004). A recent study exploited this model to show that the viral sensor molecules MDA5 and TLR3, which are both involved in IFN-I responses to viral infection, are required to prevent diabetes in mice infected with EMCV (McCartney et al. 2011). 
K.T. Coppieters et al.

A more ambiguous role is reserved for coxsackie B viruses (CVB; picornavirus, ssRNA) in the NOD mouse. Interest was sparked by the isolation of a virus resembling CVB4 from a 10-yr-old boy, which famously triggered insulitis and hyperglycemia in mice (Yoon et al. 1979). Detailed analysis in the NOD mouse revealed that coxsackieviruses provoke diabetes only when a preexisting mass of insulitis has accumulated (Serreze et al. 2000). When administered earlier, however, inoculation has a strong preventive outcome (Tracy et al. 2002; Filippi et al. 2009). This model is thus highly suitable to study the combined effect of genetically determined immunological abnormalities and an environmental factor (i.e., viral infection).

A final example of a widely studied viral mouse model differs from the previous two by the fact that the host has been genetically altered to express a viral antigen from the lymphocytic choriomeningitis virus (LCMV; arenavirus; ssRNA) on its $\beta$ cells (Ohashi et al. 1991; Oldstone et al. 1991). This is thus a pure mimicry model, in which antiviral $\mathrm{T}$ cells redirect to the $\beta$ cells after viral clearance and, depending on expression of viral antigen in the thymus, cause rapid or slow onset of clinical hyperglycemia (von Herrath et al. 1994). Our laboratory recently developed an advanced two-photon imaging approach to allow for imaging of cytotoxic T lymphocyte (CTL) effector kinetics in vivo in the pancreas using this model (Fig. 1) (Coppieters et al. 2010). Although mechanisms of cross-reactivity at play in the rat insulin promoter (RIP)-LCMV model more than likely diverge from the etiology of T1D, we propose that the behavior of activated CTL in the target tissue may still serve as a suitable model of their kinetics in T1D.

\section{Rats}

Although less commonly used as an animal model, valuable information on virus-induced diabetes has been obtained from studies in rats. A well-documented diabetogenic virus is the Kilham rat virus (KRV; parvovirus; ssDNA) that causes diabetes in the diabetes-resistant

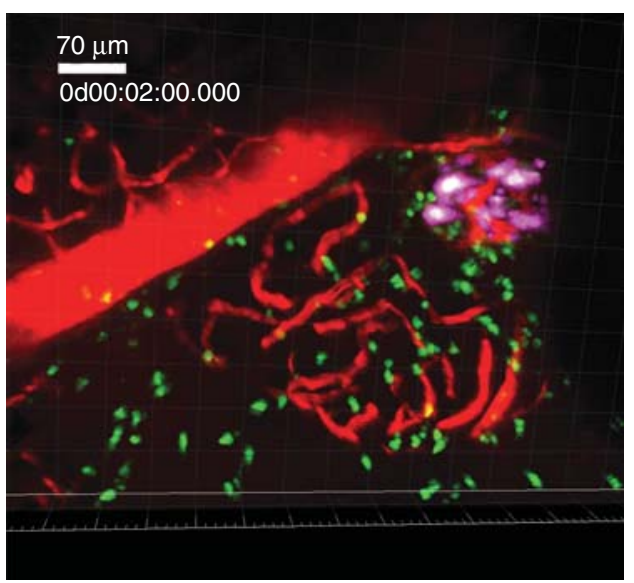

Figure 1. Antiviral, diabetogenic CTL in the RIPLCMV.GP diabetes model as visualized by intravital two-photon imaging in the pancreas. The technique is described in Coppieters et al. (2010). Briefly, purified and labeled P14 TCR-transgenic CTL is transferred to RIP-LCMV.GP hosts, followed by infection with LCMV. As such, the kinetics of the diabetogenic CTL response can be dynamically visualized in the pancreas. (Magenta) Insulin-producing $\beta$ cells, (green) CTL, (red) vasculature after dye injection.

BioBreeding (DR-BB) rat (Guberski et al. 1991). In contrast with EMCV, KRV does not infect $\beta$ cells but rather promotes diabetes by induction of autoimmunity against the $\beta$ cells. Recruitment of macrophages and perturbation of regulatory and autoreactive T-cell species have been proposed as possible mechanisms that contribute to $\beta$-cell decay in this model (Mordes et al. 2004). More recently, infection with KRV, but also rat cytomegalovirus (RCMV), was found to result in autoimmune diabetes in LEW* $1 \mathrm{WR} 1$ rats, a strain that normally experiences spontaneous onset in only $2 \%$ of cases (Tirabassi et al. 2010). Other viruses such as $H-1$, vaccinia, and CVB4, however, did not induce diabetes, indicating that diabetogenicity is virus-specific.

Table 1 lists other, less characterized, observations in mice and rats that link viral infection with diabetes development. In the following subsections we will list some of the hypotheses that have been put forward based primarily on research in the animal models outlined above (Fig. 2). 
Virus Infections in Autoimmune Diabetes

Table 1. Additional examples of viruses that can promote or prevent autoimmune diabetes in mice or rats

\begin{tabular}{|c|c|c|c|}
\hline Virus & Classification & $\begin{array}{l}\text { Host species- } \\
\text { Diabetogenicity }\end{array}$ & Reference \\
\hline Ljungan virus & Picornaviridae (ssRNA) & $\begin{array}{l}\text { Viral particles detected in } \\
\text { wild-trapped bank voles } \\
\text { and BB rats. }\end{array}$ & $\begin{array}{l}\text { Niklasson et al. 2003, } \\
2007\end{array}$ \\
\hline MHV-68 & Herperviridae (dsDNA) & $\begin{array}{l}\text { Delays diabetes in the NOD } \\
\text { in an age-dependent } \\
\text { manner. }\end{array}$ & Smith et al. 2007 \\
\hline Rotavirus & Reoviridae (dsRNA) & $\begin{array}{l}\text { Delays or accelerates } \\
\text { diabetes in the NOD in an } \\
\text { age-dependent manner. }\end{array}$ & $\begin{array}{l}\text { Graham et al. 2007, } \\
2008\end{array}$ \\
\hline Reovirus & Reoviridae (dsRNA) & $\begin{array}{l}\text { Induces diabetes and infects } \\
\beta \text { cells. Delays diabetes in } \\
\text { the NOD mouse. }\end{array}$ & $\begin{array}{l}\text { Onodera et al. 1978a; } \\
\text { Wetzel et al. } 2006\end{array}$ \\
\hline Retrovirus & Retroviridae (ssRNA) & $\begin{array}{l}\text { Presence of endogenous } \\
\text { retrovirus correlates with } \\
\text { diabetes susceptibility } \\
\text { and progression. }\end{array}$ & $\begin{array}{l}\text { Suenaga and Yoon } \\
\text { 1988; Gaskins } \\
\text { et al. } 1992\end{array}$ \\
\hline Mengovirus & Picornaviridae (ssRNA) & $\begin{array}{l}\text { Causes diabetes in addition } \\
\text { to encephalitis owing to } \\
\text { islet necrosis. }\end{array}$ & Yoon et al. 1984 \\
\hline Mouse hepatitis virus & Coronaviridae (ssRNA) & $\begin{array}{l}\text { Reduces incidence in the } \\
\text { NOD mouse. }\end{array}$ & Wilberz et al. 1991 \\
\hline $\begin{array}{l}\text { Lactate dehydrogenase } \\
\text { virus }\end{array}$ & Arteriviridae (ssRNA) & $\begin{array}{l}\text { Suppresses diabetes } \\
\text { development in the NOD } \\
\text { mouse. }\end{array}$ & Takei et al. 1992 \\
\hline
\end{tabular}

Evidence for Islet-Specific Infection

The possibility of a viral infection specifically affecting pancreatic endocrine cells constitutes a straightforward explanation for the selective demise of $\beta$ cells, either through lysis induced by cytopathic viruses or immune-mediated destruction of infected $\beta$ cells. The example of EMCV-induced diabetes highlights the potential of some viruses to specifically infect pancreatic islets and cause $\beta$-cell decay. Coxsackievirus, in contrast, displays pancreas tropism rather than a preference for $\beta$ cells, and it has been reported that it exclusively affects acinar cells while sparing the islet cells (Mena et al. 2000). Although some evidence exists that CVB can indeed infect islets in vivo (Drescher et al. 2004), it is uncertain whether the virus can persist and whether islet-specific infection is required for diabetogenicity. The detection of viral particles in the human T1D pancreas will be discussed separately.

\section{Molecular Mimicry}

The demonstration of remarkable sequence similarities between the 2C protein from coxsackievirus and a GAD65 (glutamate decarboxylase) epitope, a major target antigen in T1D, gave rise to the idea of viral mimicry in T1D (Kaufman et al. 1992). Although molecular mimicry is undoubtedly the reason for rheumatic heart disease following infection with Streptococcus pyogenes (Guilherme et al. 1995), in T1D, such type of connection proved difficult to establish. It was shown that CVB infection of young NOD mice failed to activate or expand the autoreactive precursors that are specific for those $\beta$-cell epitopes that share structural similarities with viral epitopes (Horwitz et al. 1998). Analogously, autoreactive human T-cell clones specific for the GAD65 epitope did not proliferate following stimulation with the viral epitope (Schloot et al. 2001). Studies in the mouse RIP-LCMV system suggest that complete 


\section{K.T. Coppieters et al.}

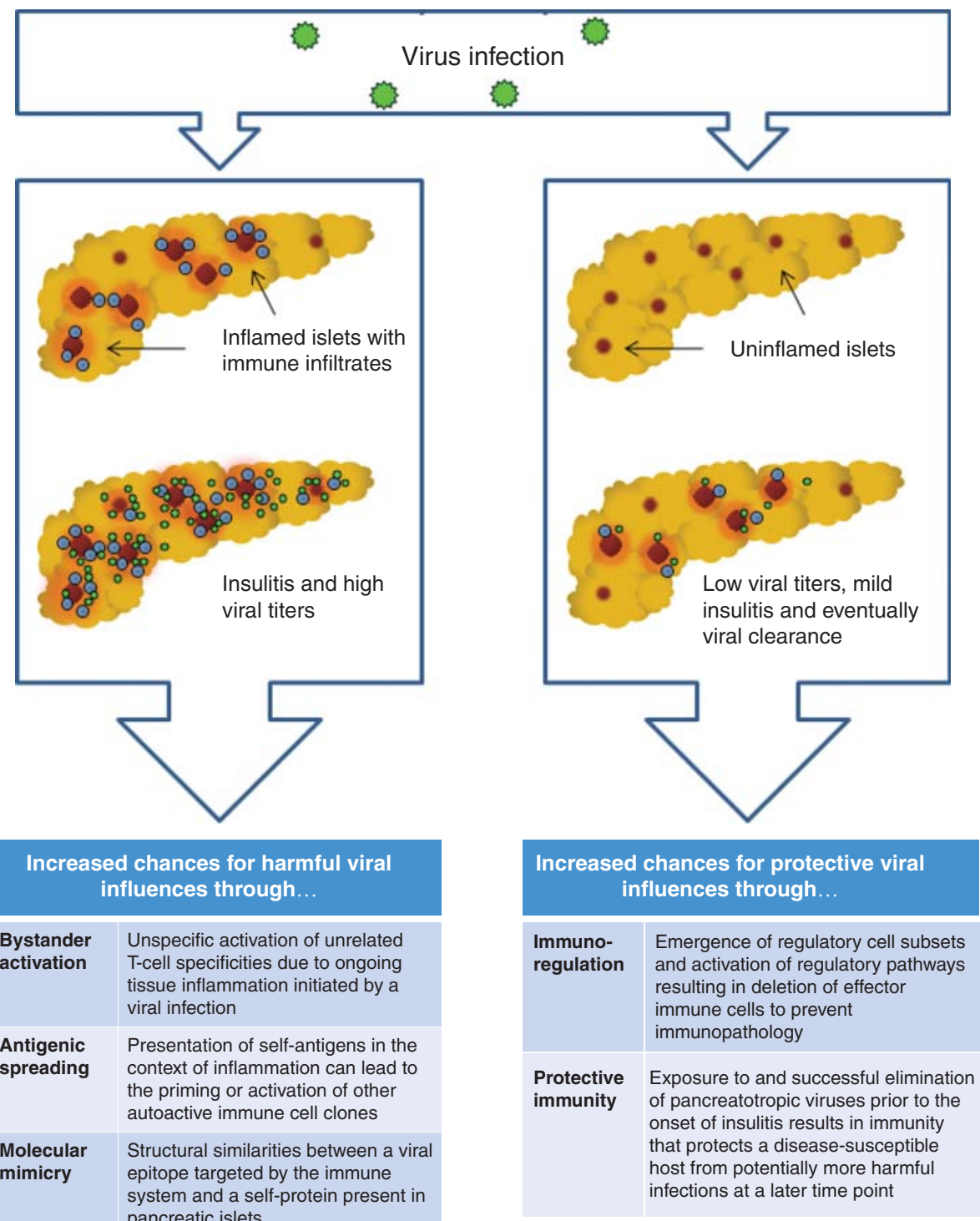

Figure 2. Potential immune mechanisms leading to islet inflammation or tolerance following viral infection.

sequence identity is required to initiate diabetes as single amino acid changes in the viral epitope on $\beta$ cells protected these mice from diabetes (Sevilla et al. 2000). Collectively, the current body of evidence favoring a simple event of cross-reactivity between viral and self-antigen is weak (Richter et al. 1994; Horwitz et al. 1998; Schloot et al. 2001). Nevertheless, molecular mimicry has been shown to accelerate disease progression under conditions of virus-induced pancreatic inflammation, suggesting that sequence homologies may not be the initiating trigger, but are able to codetermine the pace by which disease develops (Christen et al. 2004).

\section{The Concept of "Bystander" Activation}

Bystander T-cell activation is defined as the activation of a $\mathrm{T}$ cell through a mechanism that is independent of specific T-cell receptor (TCR) 
stimulation. Alternative mechanisms encompass activation through soluble factors or membrane-bound molecules that bind to receptors other than the TCR. In a strict sense, mechanisms such as "epitope spreading" or "molecular mimicry" are not included, because these involve specific recognition of a presented peptide by the TCR. Thus, bystander T-cell activation circumvents the requirement for specific TCR stimulation.

In spontaneous diabetes models, antigen specificity appears to be required for migration of autoreactive T-cell species to the pancreatic islet (Lennon et al. 2009). Recognition of islet antigens was shown to occur early at the vascular level, ensuring that only antigen-specific $\mathrm{T}$ cells can extravasate and access the islets (Savinov et al. 2003). In the context of CVB infection, circulating naive islet-specific $\mathrm{T}$ cells became activated, either through release of sequestered antigen or by "true" non-TCR bystander activation, and rapidly triggered diabetes development (Horwitz et al. 1998). However, the role for non-TCR-dependent activation of naïve $\mathrm{T}$ cells during viral infection appears limited (Ehl et al. 1997; Zarozinski and Welsh 1997).

In contrast to "bystander activation" of naïve $\mathrm{T}$ cells, the induction of "bystander damage" via, e.g., cytokine release may be the more relevant scenario during virus-induced diabetes (Seewaldt et al. 2000). Here, the $\beta$ cells are the bystanders and are killed in a non-TCR-dependent fashion through the release of soluble factors by antiviral effectors.

\section{The Fertile Field Hypothesis}

The fertile field hypothesis combines the aforementioned concepts and postulates that virusinduced inflammation preconditions ("fertilizes") the pancreas milieu for autoimmunity, which ultimately results in T1D only in susceptible individuals (von Herrath et al. 2003). Following the establishment of localized inflammation by the virus, autoreactive $\mathrm{T}$ cells are generated by molecular mimicry or bystander activation, or a combination of both. The subsequent demise of $\beta$ cells and consequent presentation of $\beta$-cell antigens in the draining lymph nodes would then lead to epitope and antigenic spreading. This would explain the emergence of a broad autoreactive T-cell repertoire over time in most T1D individuals. Mouse models of virally induced T1D and multiple sclerosis (MS) also clearly show the occurrence of secondary autoreactivity against molecules that are not initially targeted by the antiviral effectors that drive the early stages (Miller et al. 1997; Coon et al. 1999; Holz et al. 2000). Contradicting the fertile field hypothesis are studies that emphasize preexisting insulitis as a crucial prerequisite for a viral infection to cause T1D (see above). Thus, it remains to be conclusively determined whether viral infections are required to produce disease-promoting conditions in autoimmunity-prone individuals or, conversely, if preexisting autoimmunity determines the outcome of a pancreatropic viral infection.

\section{EVIDENCE FOR VIRAL INFECTION OF THE PANCREAS}

The target organ in T1D, the pancreas, is unfortunately extremely difficult to study because of its inaccessible anatomical location (Coppieters and von Herrath 2009). Owing to greatly improved clinical management of T1D, pancreas samples from recently diagnosed T1D patients today only rarely become available. Programs such as the Network for Pancreatic Organ Donors (nPOD) (www.jdrfnpod.org), aimed at the nationwide procurement of tissue relevant to T1D research, respond to this unmet need and will also offer samples from nondiabetic, islet-antibody positive individuals. At present, the important question as to whether viruses, and in particular, enteroviruses, can directly affect pancreatic islets has been addressed by a relatively small set of studies.

\section{Indirect Evidence: The "Viral Signature"}

Foulis and coworkers were the first to systematically document the hyperexpression of HLA Class I and interferon- $\alpha$ within islets of recently diagnosed diabetic children (Fig. 3) (Foulis et al. 1987). Normal islets are completely devoid of these markers. The presence of these markers 
K.T. Coppieters et al.

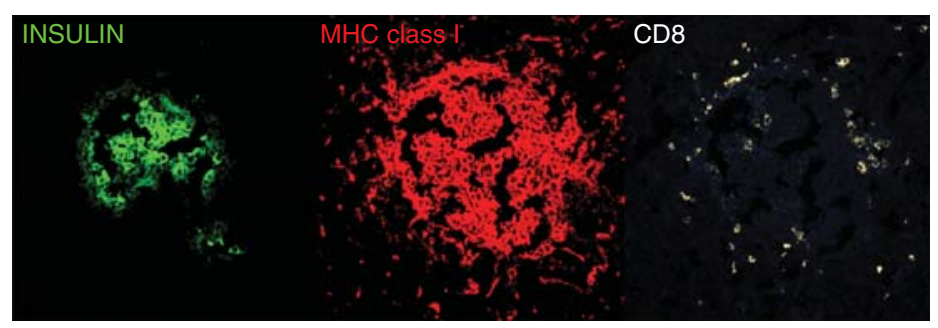

Figure 3. Aberrant MHC class I hyperexpression in islets from a 12-yr-old boy with one year of T1D duration (nPOD case 6052). Frozen pancreas section was stained for immunofluorescence and analyzed by confocal microscopy. Note the abundance of $\mathrm{CD}^{+}$cellular infiltration. (For details see Gianani et al. 2010.)

is commonly referred to as a "viral signature," as the up-regulated expression of HLA/MHC class I molecules is typically driven by type I IFNs following viral infection. The islet-specific MHC class I expression would render the cells suitable targets to CD8 T cells that are known to be an integral part of insulitic lesions. Indeed, in a mouse model of type T1D, only $\beta$ cells that have been unmasked by MHC class I expression were attacked by activated, autoreactive $\mathrm{T}$ cells, demonstrating the necessity of MHC class I up-regulation for immune-mediated $\beta$-cell destruction (von Herrath et al. 1994). In this context it is interesting to note that defined polymorphisms in the IFIH1 gene may result in lower levels of type I interferons (IFNs) in response to viral infections and may confer protection from autoimmune diabetes (Nejentsev et al. 2009).

CVB-induced hyperexpression of the interferon-inducible chemokine CXCL-10 by pancreatic islet cells was also proposed as an early molecular marker of infection (Berg et al. 2006). Its localized production was found to coincide with islet-specific enteroviral infection in fulminant T1D, but also conventional T1D (Tanaka et al. 2009; Roep et al. 2010). Some data from animal models suggests that virus-induced CXCL-10 is essential in the recruitment of CXCR- $3^{+}$autoreactive $\mathrm{T}$ cells to the islets, although recent studies in our laboratory found that CXCL10 is in fact dispensable (Christen et al. 2003) (KT Coppieters and MG von Herrath, unpubl.). Collectively, although the indispensable role of CXCL10 has yet to be confirmed, these data suggest that viral infections have the potential to establish a molecular "signature" that aids in the recruitment of diabetogenic T cells to pancreatic islets.

\section{Direct Evidence of Viral Infection of the Pancreas in T1D}

Whereas initial efforts to directly detect viral sequences in the islets from patients with MHC class I up-regulation were unsuccessful (Foulis et al. 1990, 1997), the same samples were recently revisited using a more modern methodology (Richardson et al. 2009). Using immunohistochemical detection, enteroviral particles were found in islets from 44 out of 72 recent-onset patients versus three out of 50 controls. It is worth noticing that positive detection was also achieved in 10 out of 25 type 2 diabetes patients. Another group probed 65 pancreata from T1D patients for enteroviral RNA by in situ hybridization and found enterovirus-positive islet cells in four cases, compared to none in nondiabetics (Ylipaasto et al. 2004). Likewise, Dotta and coworkers found immunohistochemical traces of enteroviral protein in three out of six pancreatic islets from recent-onset patients and corroborated these data by sequencing (Dotta et al. 2007). Of interest, islets from these patients showed an unusual, NK cell-dominated form of insulitis. In contrast to the above analyses performed after diagnosis, a recent case report sampled pancreatic tissue from an autoantibody-positive, nondiabetic child (Oikarinen et al. 2008b). It was found that the pancreatic islets had no signs of insulitis, in line with data from In't Veld et al. in a larger cohort (In't 
Veld et al. 2007). However, enterovirus was detected by immunohistochemistry specifically in the islets but not by in situ hybridization. Awaiting confirmation from larger studies, it is possible that this isolated case exposes the very early stages of T1D development, showing the establishment of local viral infection even before onset of subclinical insulitis.

Anatomical sites close to the pancreas may serve as a reservoir for viral infections in T1D. Oikarinen et al. subjected intestinal biopsies from 12 T1D patients to in situ hybridization and immunohistochemistry for enterovirus (Oikarinen et al. 2008a). Detection was achieved in $50 \%$ of T1D patients as compared to none in nondiabetic subjects. Based on these findings, the authors postulated that the gutwhich showed normal histopathological composition in all cases - could represent a chronic infectious site with close anatomical ties to the pancreatic milieu. Alternatively, immune recognition could occur at the intestinal level followed by subsequent homing of activated lymphocytes to the pancreas.

It seems rather unlikely that the majority of T1D cases are attributable to direct lysis of infected $\beta$ cells. Such a scenario would result in a more acute onset of disease, which is not the disease phenotype that is commonly observed in patients, although such cases have been described in the literature (Imagawa et al. 2000). Although evidence of enteroviral infection has been shown in these fulminant diabetes cases, the pathogenesis observed in such patients lacks the development of islet autoreactivity (e.g., islet autoantibodies), a fundamental feature of conventional T1D (Tanaka et al. 2009).

\section{DIFFICULTIES IN IDENTIFYING A ROLE FOR VIRUSES IN T1D AND THERAPEUTIC IMPLICATIONS}

\section{Temporal Divergence of Viral Insult and Clinical Onset}

Despite decades of investigation, no evidence exists for the involvement of a particular viral strain with T1D. The search for a correlation with certain viral agents can be expected to be complex for a variety of reasons. In both mouse models and T1D patients, development of clinical hyperglycemia is thought to represent the final stage of the autoimmune process. Therefore, it can be assumed that the event that initiates the loss of tolerance against islet antigens likely precedes the onset of diabetes by several months or years. This temporal discrepancy poses considerable restraints in studying the role of viral infection in T1D development, as the vast majority of patients are traditionally sampled after diagnosis. Taking into account that inciting viral agents may use a "hit-and-run" strategy, or act by repeated, sequential infection, analyses around clinical onset may at least in some occasions miss out on the culprits.

Alternatively, viral infection may only serve as an accelerating factor that, superimposed onto advanced insulitis, leads to rapid culmination into hyperglycemia. The latter scenario would suggest that detection of viral particles around onset is an achievable goal in determining a causal relationship.

\section{Multiple Viruses May Provoke Disease in Similar Fashion}

The fact that no absolute association has been identified with certain viral strains or even viral genuses or families indicates that, if T1D is indeed caused by viruses, multiple infectious strains may result in the same disease phenotype. Historically, samples from T1D patients have been probed by a "one test-one pathogen" approach that unavoidably introduces experimental bias. Whether the assay is based on detection of virus-specific antibodies or nucleic acid sequences, such strategies are costly, inefficient, and time-consuming and generally make poor usage of the limited sample volumes that are available from T1D patients. To cast the net more widely in the evaluation of a viral etiology, emerging nucleic acid technologies to detect pathogens on a broad-spectrum basis should be applied on blood and pancreas samples from T1D patients at various stages pre- and postdiagnosis. Indeed high-density microarrays, such as the Virochip pan-viral microarray and deep sequencing, can test for 
K.T. Coppieters et al.

thousands of potential pathogens simultaneously (Wang et al. 2002, 2003).

\section{Alignment with the Hygiene Hypothesis}

Based on our present knowledge, enteroviruses would appear associated with at least a fraction of T1D cases. But if enteroviruses are indeed a major contributor to T1D pathogenesis, how can we explain the increase in T1D incidence in countries where exposure to enteroviruses has been dropping (e.g., Finland) (Viskari et al. 2005)? In other words, is the theory that T1D can be caused by a viral infection compatible with the hygiene hypothesis? Based on the findings in the NOD mouse, one could argue that the lack of exposure to enteroviruses in developed countries results in a reduced frequency of individuals with protective immunity through early childhood infections. When genetically driven islet inflammation occurs in these unprotected individuals, they would be more susceptible to an enteroviral infection that has the potential to initiate overt autoreactivity and $\beta$ cell damage.

\section{Immunization Strategies: Why Not Now?}

So why don't we initiate population-wide vaccination programs to more thoroughly and directly evaluate the role of enterovirus in T1D? Theoretically, virologists deem the development of enterovirus vaccines relatively straightforward and achievable (S Tracy, pers. comm.). The main limitation at present is that the enterovirus genus of the Picornavirida family consists of five virus species. These virus species in turn contain many different strains and serologically distinct viruses (Fauquet 2005). Any one or a combination of these viruses could be the virus detected by, for example, the anti-VP1 antibody that is commonly used in immunohistochemical analysis. Finnish groups are currently attempting to delineate which enteroviral strains are most prevalent in T1D patients to clarify serotypes that should be immunized against (Roivainen 2006).

A disturbing observation related to the idea of prophylactic vaccination is the finding that
CVB infection protects against diabetes development in the young NOD mouse. This protection is orchestrated via at least two distinct suppressive immune mechanisms, the up-regulation of the inhibitory PD-1/PD-L1 pathway and increasing numbers of circulating $\mathrm{T}$ cells with regulatory capacities (Filippi et al. 2009). Such data illustrate the dual role of viral infections in autoimmunity, and portray T1D development as a balancing act between immune "education" by viruses (see "hygiene" hypothesis) and the induction of aberrant immunity in response to these agents. Moreover, they suggest that the protective effect of viral infections is a proactive mechanism that involves the emergence of regulatory mechanisms and thus, exceeds the achievement of sterile immunity which would be the ultimate goal in vaccination programs.

As a final note, the introduction of childhood immunizations programs and the growing prevalence of T1D in developed countries have also provided rationale for assessing a possible correlation between the two entities. Multiple large-scale studies found no support for any causal relation between childhood vaccination and T1D (Blom et al. 1991; EURODIAB Substudy 2 Study Group 2000; DeStefano et al. 2001; Hviid et al. 2004). As there appears to be no significant association between vaccination and T1D, the risk-benefit ratio as of today balances strongly in favor of continued protection efforts by means of immunization.

\section{CONCLUDING REMARKS}

The available data set on the role of viral infections in T1D development and progression allows us to conclude with a reasonable degree of confidence, that at least a fraction of patients at some point suffer some type of viral insult. Viruses belonging to the enterovirus genus have the capacity to initiate and/or accelerate islet autoimmunity, but cannot fully explain the etiology as a sole environmental trigger. What is needed is a comprehensive, microarray-based approach using patient samples at various stages pre- and postdiagnosis of disease. Emerging PCR-based technologies should be 
used to offer a more definitive and unbiased evaluation of the potential role of viruses in T1D pathophysiology. Results from large longitudinal follow-up studies such as DAISY and The Environmental Determinants of Diabetes in the Young (TEDDY) study are expected to contribute significantly in the near future. Indepth knowledge on which viruses act when, and at which anatomical level, could enable us to design rational vaccination approaches in susceptible individuals for T1D prevention.

\section{ACKNOWLEDGMENTS}

The sample in Figure 1 was obtained with the support of the Network for Pancreatic Organ Donors with Diabetes (nPOD), a collaborative type 1 diabetes research project sponsored by the Juvenile Diabetes Research Foundation International (JDRF). Organ Procurement Organizations (OPO) partnering with $\mathrm{nPOD}$ to provide research resources are listed at www. jdrfnpod.org/our-partners.php.

\section{REFERENCES}

Adams SF. 1926. The seasonal variation in the incidence of acute diabetes. Arch Intern Med 37: 861-864.

Bach JF. 2002. The effect of infections on susceptibility to autoimmune and allergic diseases. $N$ Engl J Med 347: 911-920.

Baek HS, Yoon JW. 1991. Direct involvement of macrophages in destruction of $\beta$-cells leading to development of diabetes in virus-infected mice. Diabetes 40: 15861597.

Banatvala JE, Bryant J, Schernthaner G, Borkenstein M, Schober E, Brown D, De Silva LM, Menser MA, Silink M. 1985. Coxsackie B, mumps, rubella, and cytomegalovirus specific IgM responses in patients with juvenileonset insulin-dependent diabetes mellitus in Britain, Austria, and Australia. Lancet 1: 1409-1412.

Berg AK, Korsgren O, Frisk G. 2006. Induction of the chemokine interferon- $\gamma$-inducible protein-10 in human pancreatic islets during enterovirus infection. Diabetologia 49: 2697-2703.

Blom L, Nystrom L, Dahlquist G. 1991. The Swedish childhood diabetes study. Vaccinations and infections as risk determinants for diabetes in childhood. Diabetologia 34: $176-181$.

Blomqvist M, Juhela S, Erkkila S, Korhonen S, Simell T, Kupila A, Vaarala O, Simell O, Knip M, Ilonen J. 2002. Rotavirus infections and development of diabetes-associated autoantibodies during the first 2 years of life. Clin Exp Immunol 128: 511-515.
Bodansky HJ, Staines A, Stephenson C, Haigh D, Cartwright R. 1992. Evidence for an environmental effect in the aetiology of insulin dependent diabetes in a transmigratory population. BMJ 304: 1020-1022.

Borchers AT, Uibo R, Gershwin ME. 2010. The geoepidemiology of type 1 diabetes. Autoimmun Rev 9: A355-A365.

Christen U, McGavern DB, Luster AD, von Herrath MG, Oldstone MB. 2003. Among CXCR3 chemokines, IFN- $\gamma$-inducible protein of $10 \mathrm{kDa}$ (CXC chemokine ligand [CXCL] 10) but not monokine induced by IFN- $\gamma$ (CXCL9) imprints a pattern for the subsequent development of autoimmune disease. J Immunol 171: 6838-6845.

Christen U, Edelmann KH, McGavern DB, Wolfe T, Coon B, Teague MK, Miller SD, Oldstone MB, von Herrath MG. 2004. Aviral epitope that mimics a self antigen can accelerate but not initiate autoimmune diabetes. J Clin Invest 114: $1290-1298$

Clements GB, Galbraith DN, Taylor KW. 1995. Coxsackie B virus infection and onset of childhood diabetes. Lancet 346: $221-223$.

Conrad B, Weissmahr RN, Boni J, Arcari R, Schupbach J, Mach B. 1997. A human endogenous retroviral superantigen as candidate autoimmune gene in type I diabetes. Cell 90: 303-313.

Coon B, An LL, Whitton JL, von Herrath MG. 1999. DNA immunization to prevent autoimmune diabetes. J Clin Invest 104: 189-194.

Coppieters KT, von Herrath MG. 2009. Histopathology of type 1 diabetes: Old paradigms and new insights. Rev Diabet Stud 6: 85-96.

Coppieters K, Martinic MM, Kiosses WB, Amirian N, von Herrath M. 2010. A novel technique for the in vivo imaging of autoimmune diabetes development in the pancreas by two-photon microscopy. PLoS One 5: e15732.

Craighead JE, McLane MF. 1968. Diabetes mellitus: Induction in mice by encephalomyocarditis virus. Science 162: $913-914$.

Dahlquist G, Frisk G, Ivarsson SA, Svanberg L, Forsgren M, Diderholm H. 1995. Indications that maternal coxsackie $\mathrm{B}$ virus infection during pregnancy is a risk factor for childhood-onset IDDM. Diabetologia 38: 1371-1373.

DeStefano F, Mullooly JP, Okoro CA, Chen RT, Marcy SM, Ward JI, Vadheim CM, Black SB, Shinefield HR, Davis RL, et al. 2001. Childhood vaccinations, vaccination timing, and risk of type 1 diabetes mellitus. Pediatrics 108: E112.

Dippe SE, Bennett PH, Miller M, Maynard JE, Berquist KR. 1975. Lack of causal association between Coxsackie B4 virus infection and diabetes. Lancet 1: 1314-1317.

Dotta F, Censini S, van Halteren AG, Marselli L, Masini M, Dionisi S, Mosca F, Boggi U, Muda AO, Prato SD, et al. 2007. Coxsackie B4 virus infection of $\beta$ cells and natural killer cell insulitis in recent-onset type 1 diabetic patients. Proc Natl Acad Sci 104: 5115-5120.

Drescher KM, Kono K, Bopegamage S, Carson SD, Tracy S. 2004. Coxsackievirus B3 infection and type 1 diabetes development in NOD mice: Insulitis determines susceptibility of pancreatic islets to virus infection. Virology 329: $381-394$. 
K.T. Coppieters et al.

Ehl S, Hombach J, Aichele P, Hengartner H, Zinkernagel RM. 1997. Bystander activation of cytotoxic T cells: Studies on the mechanism and evaluation of in vivo significance in a transgenic mouse model. J Exp Med 185: $1241-1251$.

Elfving M, Svensson J, Oikarinen S, Jonsson B, Olofsson P, Sundkvist G, Lindberg B, Lernmark A, Hyoty H, Ivarsson SA. 2008. Maternal enterovirus infection during pregnancy as a risk factor in offspring diagnosed with type 1 diabetes between 15 and 30 years of age. Exp Diabetes Res 2008: 271958.

EURODIAB Substudy 2 Study Group. 2000. Infections and vaccinations as risk factors for childhood type I (insulindependent) diabetes mellitus: A multicentre case-control investigation. Diabetologia 43: 47-53.

Fauquet CM, Mayo MA, Maniloff J, Desselberger U, Ball LA 2005. Virus taxonomy: Eighth report of the international committee on taxonomy of viruses. Academic Press, San Diego.

Filippi CM, Estes EA, Oldham JE, von Herrath MG. 2009. Immunoregulatory mechanisms triggered by viral infections protect from type 1 diabetes in mice. J Clin Invest 119: $1515-1523$.

Foulis AK, Farquharson MA, Meager A. 1987. Immunoreactive $\alpha$-interferon in insulin-secreting $\beta$ cells in type 1 diabetes mellitus. Lancet 2: 1423-1427.

Foulis AK, Farquharson MA, Cameron SO, McGill M, Schonke H, Kandolf R. 1990. A search for the presence of the enteroviral capsid protein VP1 in pancreases of patients with type 1 (insulin-dependent) diabetes and pancreases and hearts of infants who died of coxsackieviral myocarditis. Diabetologia 33: 290-298.

Foulis AK, McGill M, Farquharson MA, Hilton DA. 1997. A search for evidence of viral infection in pancreases of newly diagnosed patients with IDDM. Diabetologia 40: 53-61.

Fuchtenbusch M, Irnstetter A, Jager G, Ziegler AG. 2001. No evidence for an association of coxsackie virus infections during pregnancy and early childhood with development of islet autoantibodies in offspring of mothers or fathers with type 1 diabetes. J Autoimmun 17: 333-340.

Gale EA. 2008. Congenital rubella: Citation virus or vira cause of type 1 diabetes? Diabetologia 51: 1559-1566.

Gamble DR, Kinsley ML, FitzGerald MG, Bolton R, Taylor KW. 1969. Viral antibodies in diabetes mellitus. $\mathrm{Br}$ Med J 3: 627-630.

Gaskins HR, Prochazka M, Hamaguchi K, Serreze DV, Leiter EH. 1992. $\beta$ cell expression of endogenous xenotropic retrovirus distinguishes diabetes-susceptible NOD/Lt from resistant NON/Lt mice. J Clin Invest 90: 2220 2227.

Gianani R, Campbell-Thompson M, Sarkar SA, Wasserfall C, Pugliese A, Solis JM, Kent SC, Hering BJ, West E, Steck A, et al. 2010. Dimorphic histopathology of long-standing childhood-onset diabetes. Diabetologia 53: 690-698.

Gillespie KM, Bain SC, Barnett AH, Bingley PJ, Christie MR, Gill GV, Gale EA. 2004. The rising incidence of childhood type 1 diabetes and reduced contribution of high-risk HLA haplotypes. Lancet 364: 1699-1700.

Goto A, Takahashi Y, Kishimoto M, Nakajima Y, Nakanishi K, Kajio H, Noda M. 2008. A case of fulminant type 1 dia- betes associated with significant elevation of mumps titers. Endocr J 55: 561-564.

Graham KL, O'Donnell JA, Tan Y, Sanders N, Carrington EM, Allison J, Coulson BS. 2007. Rotavirus infection of infant and young adult nonobese diabetic mice involves extraintestinal spread and delays diabetes onset. J Virol 81: 6446-6458.

Graham KL, Sanders N, Tan Y, Allison J, Kay TW, Coulson BS. 2008. Rotavirus infection accelerates type 1 diabetes in mice with established insulitis. J Virol 82: 6139-6149.

Graves PM, Rotbart HA, Nix WA, Pallansch MA, Erlich HA Norris JM, Hoffman M, Eisenbarth GS, Rewers M. 2003. Prospective study of enteroviral infections and development of $\beta$-cell autoimmunity. Diabetes autoimmunity study in the young (DAISY). Diabetes Res Clin Pract 59: $51-61$.

Guberski DL, Thomas VA, Shek WR, Like AA, Handler ES, Rossini AA, Wallace JE, Welsh RM. 1991. Induction of type I diabetes by Kilham's rat virus in diabetes-resistant BB/Wor rats. Science 254: 1010-1013.

Guilherme L, Cunha-Neto E, Coelho V, Snitcowsky R, Pomerantzeff PM, Assis RV, Pedra F, Neumann J, Goldberg A, Patarroyo ME, et al. 1995. Human heart-infiltrating T-cell clones from rheumatic heart disease patients recognize both streptococcal and cardiac proteins. Circulation 92: 415-420.

Harjutsalo V, Sjoberg L, Tuomilehto J. 2008. Time trends in the incidence of type 1 diabetes in Finnish children: A cohort study. Lancet 371: 1777-1782.

Holz A, Dyrberg T, Hagopian W, Homann D, von Herrath M, Oldstone MB. 2000. Neither B lymphocytes nor antibodies directed against self antigens of the islets of Langerhans are required for development of virus-induced autoimmune diabetes. J Immunol 165: 59455953.

Honeyman M. 2005. How robust is the evidence for viruses in the induction of type 1 diabetes? Curr Opin Immunol 17: 616-623.

Honeyman MC, Stone NL, Harrison LC. 1998. T-cell epitopes in type 1 diabetes autoantigen tyrosine phosphatase IA-2: Potential for mimicry with rotavirus and other environmental agents. Mol Med 4: 231-239.

Honeyman MC, Coulson BS, Stone NL, Gellert SA, Goldwater PN, Steele CE, Couper JJ, Tait BD, Colman PG, Harrison LC. 2000. Association between rotavirus infection and pancreatic islet autoimmunity in children at risk of developing type 1 diabetes. Diabetes 49: 1319-1324.

Horwitz MS, Bradley LM, Harbertson J, Krahl T, Lee J, Sarvetnick N. 1998. Diabetes induced by Coxsackie virus: Initiation by bystander damage and not molecular mimicry. Nat Med 4: 781-785.

Horwitz MS, Fine C, Ilic A, Sarvetnick N. 2001. Requirements for viral-mediated autoimmune diabetes: $\beta$-cell damage and immune infiltration. J Autoimmun 16: 211-217.

Hviid A, Stellfeld M, Wohlfahrt J, Melbye M. 2004. Childhood vaccination and type 1 diabetes. $N$ Engl J Med 350: $1398-1404$

Hyoty H, Hiltunen M, Knip M, Laakkonen M, Vahasalo P Karjalainen J, Koskela P, Roivainen M, Leinikki P, Hovi T, et al. 1995. A prospective study of the role of coxsackie $\mathrm{B}$ and other enterovirus infections in the pathogenesis of 
IDDM. Childhood Diabetes in Finland (DiMe) Study Group. Diabetes 44: 652-657.

Imagawa A, Hanafusa T, Miyagawa J, Matsuzawa Y. 2000. A novel subtype of type 1 diabetes mellitus characterized by a rapid onset and an absence of diabetes-related antibodies. Osaka IDDM Study Group. N Engl J Med 342: 301-307.

In't Veld P, Lievens D, De Grijse J, Ling Z, Van der Auwera B, Pipeleers-Marichal M, Gorus F, Pipeleers D. 2007. Screening for insulitis in adult autoantibody-positive organ donors. Diabetes 56: 2400-2404.

Kasuga A, Harada R, Saruta T. 1996. Insulin-dependent diabetes mellitus associated with parvovirus B19 infection. Ann Intern Med 125: 700-701.

Kaufman DL, Erlander MG, Clare-Salzler M, Atkinson MA, Maclaren NK, Tobin AJ. 1992. Autoimmunity to two forms of glutamate decarboxylase in insulin-dependent diabetes mellitus. J Clin Invest 89: 283-292.

Lennon GP, Bettini M, Burton AR, Vincent E, Arnold PY, Santamaria P, Vignali DA. 2009. T cell islet accumulation in type 1 diabetes is a tightly regulated, cell-autonomous event. Immunity 31: 643-653.

Makela M, Oling V, Marttila J, Waris M, Knip M, Simell O, Ilonen J. 2006. Rotavirus-specific T cell responses and cytokine mRNA expression in children with diabetesassociated autoantibodies and type 1 diabetes. Clin Exp Immunol 145: 261-270.

McCartney SA, Vermi W, Lonardi S, Rossini C, Otero K, Calderon B, Gilfillan S, Diamond MS, Unanue ER, Colonna M. 2011. RNA sensor-induced type I IFN prevents diabetes caused by a $\beta$ cell-tropic virus in mice. J Clin Invest 121: 1497-1507.

Mena I, Fischer C, Gebhard JR, Perry CM, Harkins S, Whitton JL. 2000. Coxsackievirus infection of the pancreas: Evaluation of receptor expression, pathogenesis, and immunopathology. Virology 271: 276-288.

Menser MA, Forrest JM, Honeyman MC, Burgess JA. 1974. Letter: Diabetes, HL-A antigens, and congenital rubella. Lancet 2: $1508-1509$.

Miller SD, Vanderlugt CL, Begolka WS, Pao W, Yauch RL, Neville KL, Katz-Levy Y, Carrizosa A, Kim BS. 1997. Persistent infection with Theiler's virus leads to CNS autoimmunity via epitope spreading. Nat Med 3: 1133-1136.

Mordes JP, Bortell R, Blankenhorn EP, Rossini AA, Greiner DL. 2004. Rat models of type 1 diabetes: Genetics, environment, and autoimmunity. Ilar J 45: 278-291.

Nejentsev S, Walker N, Riches D, Egholm M, Todd JA. 2009. Rare variants of IFIH1, a gene implicated in antiviral responses, protect against type 1 diabetes. Science 324: 387-389.

Niklasson B, Hornfeldt B, Nyholm E, Niedrig M, DonosoMantke O, Gelderblom HR, Lernmark A. 2003. Type 1 diabetes in Swedish bank voles (Clethrionomys glareolus): Signs of disease in both colonized and wild cyclic populations at peak density. Ann NY Acad Sci 1005: 170-175.

Niklasson B, Hultman T, Kallies R, Niedrig M, Nilsson R, Berggren PO, Juntti-Berggren L, Efendic S, Lernmark A, Klitz W. 2007. The BioBreeding rat diabetes model is infected with Ljungan virus. Diabetologia 50: 1559-1560.

Ohashi PS, Oehen S, Buerki K, Pircher H, Ohashi CT, Odermatt B, Malissen B, Zinkernagel RM, Hengartner H.
1991. Ablation of "tolerance" and induction of diabetes by virus infection in viral antigen transgenic mice. Cell 65: 305-317.

Oikarinen M, Tauriainen S, Honkanen T, Oikarinen S, Vuori K, Kaukinen K, Rantala I, Maki M, Hyoty H. 2008a. Detection of enteroviruses in the intestine of type 1 diabetic patients. Clin Exp Immunol 151: 71-75.

Oikarinen M, Tauriainen S, Honkanen T, Vuori K, Karhunen P, Vasama-Nolvi C, Oikarinen S, Verbeke C, Blair GE, Rantala I, et al. 2008b. Analysis of pancreas tissue in a child positive for islet cell antibodies. Diabetologia 51: 1796-1802.

Oikarinen S, Martiskainen M, Tauriainen S, Huhtala H, Ilonen J, Veijola R, Simell O, Knip M, Hyoty H. 2011. Enterovirus RNA in blood is linked to the development of type 1 diabetes. Diabetes 60: 276-279.

Oldstone MB, Nerenberg M, Southern P, Price J, Lewicki H. 1991. Virus infection triggers insulin-dependent diabetes mellitus in a transgenic model: Role of anti-self (virus) immune response. Cell 65: 319-331.

Onodera T, Jenson AB, Yoon JW, Notkins AL. 1978a. Virus-induced diabetes mellitus: Reovirus infection of pancreatic $\beta$ cells in mice. Science 201: $529-531$.

Onodera T, Yoon JW, Brown KS, Notkina AL. 1978b. Evidence for a single locus controlling susceptibility to virus-induced diabetes mellitus. Nature 274: 693-696.

Pak CY, Eun HM, McArthur RG, Yoon JW. 1988. Association of cytomegalovirus infection with autoimmune type 1 diabetes. Lancet 2: 1-4.

Patterson K, Chandra RS, Jenson AB. 1981. Congenital rubella, insulitis, and diabetes mellitus in an infant. Lancet 1: $1048-1049$.

Redondo MJ, Jeffrey J, Fain PR, Eisenbarth GS, Orban T. 2008. Concordance for islet autoimmunity among monozygotic twins. N Engl J Med 359: 2849-2850.

Richardson SJ, Willcox A, Bone AJ, Foulis AK, Morgan NG. 2009. The prevalence of enteroviral capsid protein vp1 immunostaining in pancreatic islets in human type 1 diabetes. Diabetologia 52: 1143-1151.

Richter W, Mertens T, Schoel B, Muir P, Ritzkowsky A, Scherbaum WA, Boehm BO. 1994. Sequence homology of the diabetes-associated autoantigen glutamate decarboxylase with coxsackie $\mathrm{B} 4-2 \mathrm{C}$ protein and heat shock protein 60 mediates no molecular mimicry of autoantibodies. J Exp Med 180: 721-726.

Roep BO, Kleijwegt FS, van Halteren AG, Bonato V, Boggi U, Vendrame F, Marchetti P, Dotta F. 2010. Islet inflammation and CXCL10 in recent-onset type 1 diabetes. Clin Exp Immunol 159: 338-343.

Roivainen M. 2006. Enteroviruses: New findings on the role of enteroviruses in type 1 diabetes. Int J Biochem Cell Biol 38: $721-725$.

Sadeharju K, Lonnrot M, Kimpimaki T, Savola K, Erkkila S, Kalliokoski T, Savolainen P, Koskela P, Ilonen J, Simell O, et al. 2001. Enterovirus antibody levels during the first two years of life in prediabetic autoantibody-positive children. Diabetologia 44: 818-823.

Savinov AY, Wong FS, Stonebraker AC, Chervonsky AV. 2003. Presentation of antigen by endothelial cells and chemoattraction are required for homing of insulin-specific CD8 ${ }^{+}$T cells. J Exp Med 197: 643-656. 
K.T. Coppieters et al.

Schloot NC, Willemen SJ, Duinkerken G, Drijfhout JW, de Vries RR, Roep BO. 2001. Molecular mimicry in type 1 diabetes mellitus revisited: T-cell clones to GAD65 peptides with sequence homology to Coxsackie or proinsulin peptides do not crossreact with homologous counterpart. Hum Immunol 62: 299-309.

Seewaldt S, Thomas HE, Ejrnaes M, Christen U, Wolfe T, Rodrigo E, Coon B, Michelsen B, Kay TW, von Herrath MG. 2000. Virus-induced autoimmune diabetes: Most $\beta$-cells die through inflammatory cytokines and not perforin from autoreactive (anti-viral) cytotoxic T-lymphocytes. Diabetes 49: 1801-1809.

Serreze DV, Ottendorfer EW, Ellis TM, Gauntt CJ, Atkinson MA. 2000. Acceleration of type 1 diabetes by a coxsackievirus infection requires a preexisting critical mass of autoreactive T-cells in pancreatic islets. Diabetes 49: $708-711$.

Sevilla N, Homann D, von Herrath M, Rodriguez F, Harkins S, Whitton JL, Oldstone MB. 2000. Virus-induced diabetes in a transgenic model: Role of cross-reacting viruses and quantitation of effector T cells needed to cause disease. J Virol 74: 3284-3292.

Shimada A, Maruyama T. 2004. Encephalomyocarditis-virus-induced diabetes model resembles "fulminant" type 1 diabetes in humans. Diabetologia 47: 1854-1855.

Smith KA, Efstathiou S, Cooke A. 2007. Murine gammaherpesvirus-68 infection alters self-antigen presentation and type 1 diabetes onset in NOD mice. J Immunol 179: $7325-7333$.

Stene LC, Oikarinen S, Hyoty H, Barriga KJ, Norris JM, Klingensmith G, Hutton JC, Erlich HA, Eisenbarth GS, Rewers M. 2010. Enterovirus infection and progression from islet autoimmunity to type 1 diabetes: The diabetes and autoimmunity study in the young (DAISY). Diabetes 59: 3174-3180.

Suenaga K, Yoon JW. 1988. Association of $\beta$-cell-specific expression of endogenous retrovirus with development of insulitis and diabetes in NOD mouse. Diabetes 37: 1722-1726.

Takei I, Asaba Y, Kasatani T, Maruyama T, Watanabe K, Yanagawa T, Saruta T, Ishii T. 1992. Suppression of development of diabetes in NOD mice by lactate dehydrogenase virus infection. J Autoimmun 5: 665-673.

Tanaka S, Nishida Y, Aida K, Maruyama T, Shimada A, Suzuki M, Shimura H, Takizawa S, Takahashi M, Akiyama D, et al. 2009. Enterovirus infection, CXC chemokine ligand 10 (CXCL10), and CXCR3 circuit: A mechanism of accelerated $\beta$-cell failure in fulminant type 1 diabetes. Diabetes 58: 2285-2291.

Tirabassi RS, Guberski DL, Blankenhorn EP, Leif JH, Woda BA, Liu Z, Winans D, Greiner DL, Mordes JP. 2010. Infection with viruses from several families triggers autoimmune diabetes in LEW* 1 WR1 rats: Prevention of diabetes by maternal immunization. Diabetes 59: 110-118.

Tracy S, Drescher KM, Chapman NM, Kim KS, Carson SD, Pirruccello S, Lane PH, Romero JR, Leser JS. 2002. Toward testing the hypothesis that group B coxsackieviruses (CVB) trigger insulin-dependent diabetes: Inoculating nonobese diabetic mice with CVB markedly lowers diabetes incidence. J Virol 76: 12097-12111.

Viskari H, Ludvigsson J, Uibo R, Salur L, Marciulionyte D, Hermann R, Soltesz G, Fuchtenbusch M, Ziegler AG, Kondrashova A, et al. 2005. Relationship between the incidence of type 1 diabetes and maternal enterovirus antibodies: Time trends and geographical variation. Diabetologia 48: 1280-1287.

von Herrath MG, Dockter J, Oldstone MB. 1994. How virus induces a rapid or slow onset insulin-dependent diabetes mellitus in a transgenic model. Immunity 1: 231-242.

von Herrath MG, Fujinami RS, Whitton JL. 2003. Microorganisms and autoimmunity: Making the barren field fertile? Nat Rev Microbiol 1: 151-157.

Wang D, Coscoy L, Zylberberg M, Avila PC, Boushey HA, Ganem D, DeRisi JL. 2002. Microarray-based detection and genotyping of viral pathogens. Proc Natl Acad Sci 99: $15687-15692$.

Wang D, Urisman A, Liu YT, Springer M, Ksiazek TG, Erdman DD, Mardis ER, Hickenbotham M, Magrini V, Eldred J, et al. 2003. Viral discovery and sequence recovery using DNA microarrays. PLoS Biol 1: E2.

Wetzel JD, Barton ES, Chappell JD, Baer GS, MochowGrundy M, Rodgers SE, Shyr Y, Powers AC, Thomas JW, Dermody TS. 2006. Reovirus delays diabetes onset but does not prevent insulitis in nonobese diabetic mice. J Virol 80: 3078-3082.

Wilberz S, Partke HJ, Dagnaes-Hansen F, Herberg L. 1991. Persistent MHV (mouse hepatitis virus) infection reduces the incidence of diabetes mellitus in non-obese diabetic mice. Diabetologia 34: 2-5.

Yeung WC, Rawlinson WD, Craig ME. 2011. Enterovirus infection and type 1 diabetes mellitus: Systematic review and meta-analysis of observational molecular studies. BMJ 342: d35.

Ylipaasto P, Klingel K, Lindberg AM, Otonkoski T, Kandolf R, Hovi T, Roivainen M. 2004. Enterovirus infection in human pancreatic islet cells, islet tropism in vivo and receptor involvement in cultured islet $\beta$ cells. Diabetologia 47: 225-239.

Yoon JW, Jun HS. 2006. Viruses cause type 1 diabetes in animals. Ann NY Acad Sci 1079: 138-146.

Yoon JW, Onodera T, Notkins AL. 1978. Virus-induced diabetes mellitus. XV. $\beta$ cell damage and insulin-dependent hyperglycemia in mice infected with coxsackie virus B4. J Exp Med 148: 1068-1080.

Yoon JW, Austin M, Onodera T, Notkins AL. 1979. Isolation of a virus from the pancreas of a child with diabetic ketoacidosis. New Engl J Med 300: 1173-1179.

Yoon JW, Morishima T, McClintock PR, Austin M, Notkins AL. 1984. Virus-induced diabetes mellitus: Mengovirus infects pancreatic $\beta$ cells in strains of mice resistant to the diabetogenic effect of encephalomyocarditis virus. Virol 50: 684-690.

Zarozinski CC, Welsh RM. 1997. Minimal bystander activation of CD8 T cells during the virus-induced polyclonal T cell response. J Exp Med 185: 1629-1639. 


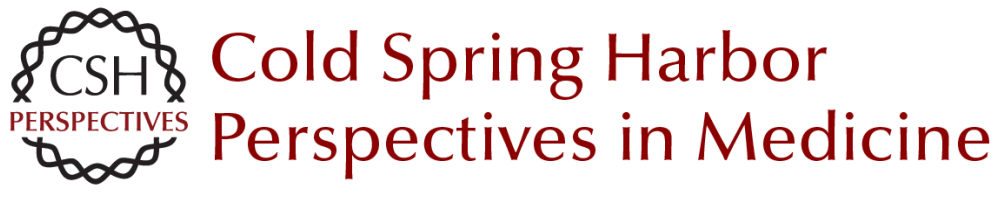

\section{Virus Infections in Type 1 Diabetes}

Ken T. Coppieters, Tobias Boettler and Matthias von Herrath

Cold Spring Harb Perspect Med 2012; doi: 10.1101/cshperspect.a007682 originally published online November 22, 2011

\section{Subject Collection Type I Diabetes}

The Pathogenesis and Natural History of Type 1 Diabetes

Mark A. Atkinson

Do MHCII-Presented Neoantigens Drive Type 1

Diabetes and Other Autoimmune Diseases?

Philippa Marrack and John W. Kappler

Clinical Immunologic Interventions for the

Treatment of Type 1 Diabetes

Lucienne Chatenoud, Katharina Warncke and

Anette-G. Ziegler

Update on Islet Transplantation

Michael McCall and A.M. James Shapiro

Immunologic and Metabolic Biomarkers of $\beta$-Cell

Destruction in the Diagnosis of Type 1 Diabetes Jasmin Lebastchi and Kevan C. Herold

Advancing Animal Models of Human Type 1

Diabetes by Engraftment of Functional Human

Tissues in Immunodeficient Mice Michael A. Brehm, Alvin C. Powers, Leonard D. Shultz, et al.

Breakdown in Peripheral Tolerance in Type 1 Diabetes in Mice and Humans

Lukas T. Jeker, Hélène Bour-Jordan and Jeffrey $A$. Bluestone

Antigen-Specific Therapeutic Approaches in Type 1 Diabetes

Xavier Clemente-Casares, Sue Tsai, Carol Huang, et al.
Humoral Autoimmunity in Type 1 Diabetes:

Prediction, Significance, and Detection of Distinct

Disease Subtypes

Massimo Pietropaolo, Roberto Towns and George S. Eisenbarth

Endoplasmic Reticulum Stress, Pancreatic $\beta$-Cell

Degeneration, and Diabetes

Feroz R. Papa

Islet Autoantigens: Structure, Function,

Localization, and Regulation

Peter Arvan, Massimo Pietropaolo, David Ostrov, et al.

Environmental Triggers of Type 1 Diabetes Mikael Knip and Olli Simell

Generating $\beta$ Cells from Stem Cells--The Story So

Far Matthias Hebrok

Antigen Targets of Type 1 Diabetes Autoimmunity Bart O. Roep and Mark Peakman

Connecting Type 1 and Type 2 Diabetes through Innate Immunity Justin I. Odegaard and Ajay Chawla

The Hygiene Hypothesis: An Explanation for the Increased Frequency of Insulin-Dependent Diabetes Jean-François Bach and Lucienne Chatenoud

For additional articles in this collection, see http://perspectivesinmedicine.cshlp.org/cgi/collection/ 